\title{
THE ROLE OF SELF-TRANSLATION IN THE DECOLONISA- TION PROCESS OF AFRICAN COUNTRIES
}

\author{
Elena BAN Dín \\ Universidad de León
}

1. Self-translation: a particular case of (literary) translation.

Since Translation Studies emerged as an academic discipline, little attention has been paid to the phenomenon of self-translation. There exists no empirical or descriptive research in the field of DTS concerned with self-translation. It is not even mentioned in the academic discourse of Translation Studies. Selftranslation cannot be said to be a non-existent or an infrequent phenomenon. On the contrary, throughout literary and non-literary history, well-known writers, scholars and philosophers have translated their own works, for example, Ramón Llull, Nebrija, Thomas More, Fray Luis de León, John Donne, Spinoza, Voltaire, Marx, Samuel Beckett, Pirandello, Nabokov and Tagore (Santoyo 2002). However, publishers, literary critics and scholars often even ignore the fact that a translation has been produced by the author himself once the work was published in the source language. Why is there such a void in Translation Studies? One reason could be that many al ready well-known theories and definitions of equivalence would be reversed and notions such as acceptability, fidelity and adequacy would need to be revisited. A more dynamic and functional view of equivalence is needed regarding self-translation. Toury's model based on the Polysystem theory rejects previous theories based on the notion of equivalence because they were source-oriented theories (Toury 1980). Instead, His model is based on difference and assumes structural differences between languages. (...) Positing hypothetical poles of total acceptability in the target culture at the one extreme and total adequacy to the source text at the other, Toury locates translation as always in the middle: no translation is ever entirely 'acceptable' to the target culture (...), nor is any translation entirely 'adequate' to the original version (Gentzler 2001: 126).

Some critics think that a translation produced by the author himself cannot be regarded as a translation of the original but as a new version or recreation of the original. Several controversial questions arise concerning self-translation: Can it be considered a "faithful"translation? Should the author-translator be faithful to the original work? There is no doubt that the author-translator is free to introduce changes in his work. The author is a writer and a translator at the same time. He has "le droit d'être infidèle"(Oustinoff 2001: 8). Michaël Oustinoff in Bilinguisme d'écriture et auto-traduction (2001) points out the creative character of self-translation. Self-translating is parallel to writing, both being creative processes carried out by the author-translator. Professional translators lack the freedom an author-translator possesses because "I'auteur est libre non seulement d'entrecroiser les textes selon son bon vouloir, mais également de recourir à tel ou tel procédé de traduction selon les circonstances"(Oustinoff 2001: 12). Ousti- 
noff also questions the status of a self-translation in relation to the original text: Is it a real translation or is it une seconde création? Oustinoff refers to selftranslation as being a texte, second original,"version, une autre oeuvre, recréation. It sees to be clear that the self-translation has an authority of its own that the translation lacks.

Christopher Whyte (2002: 64) proposes in his article "Against SelfTranslation"a definition of self-translation in a literary sense: "it means that the author of a literary text completed in one language subsequently reproduces it in a second language". Obviously, this is a narrow view of the process because it is limited to literary works, although there is evidence of the presence of selftranslation in other fields distinct from the literary one. Furthermore, Whyte's definition of self-translation does not take into account the relationship that the writer has with both languages. Self-translators are bilingual writers. They are able to write their work in any of the two languages and both can be their source language.

By contrast, we propose a wider definition of the process of self-translating as the process by which a bilingual author transfers his/ her own (literary or non-literary) work from one language to another. In this definition, notions of source language and target language are blurred due to the fact that the author is presumed to be perfectly competent in both languages and either of those languages can be the source language or the target language. Many authors may even be unsure about which language is their dominant one (Lopez Gaseni 2002) because they live 'in-between'. They inhabit the space that exists between two languages and two cultures. They do not belong to one language group but to both, and at the same time. They are part of both languages and cultures, and as a result, they have to live with the tensions inherent in such a situation. They have a hyphenated identity since they live in the slot occupied by a hyphen. That hyphen is also present in the word self-translation. According to the English Language Dictionary, a hyphen is 'a sign used to join words together to make a compound'1. In a metaphorical sense an author-translator combines two languages and two cultures in his work, since it must be seen as a compound of both, although the same work is written in two different languages. In order to study and analyse the work of self-translators, one should pay attention to their 'original' works as well as their self-translations, because the notion of primary and secondary text is also blurred since a self-translation cannot be considered only in terms of fidelity or equivalence to another previously written text. It is a re creation of the first text, a dialogue with that previous work.

N owadays self-translation is very common especially in regions characterised by linguistic diversity and bilinguism: Spain, Canada, U.S.A., Ireland, India, Africa. Since the author-translator lives between two languages and two cultures, self-translation cannot be studied in isolation, but in relation to concepts of

\footnotetext{
${ }^{1}$ English Language Dictionary. Collins Cobuild.
} 
language, culture and society. It is also closely related to questions of identity and hybridisation. Author-translators are bilingual, because they have a bilingual identity. They maintain a different relationship with each language and each culture. Whyte is concerned with the practice of self-translation within an Irish environment, where English and Gaelic maintain a prestige-non prestige relationship and the use of one or the other carries strong political connotations. Speaking about his own experience Whyte (2002: 65) argues, "that the practice of self-translation was not a voluntary choice but an imposition". In this statement, we can find some implicit ideological and political connotations. Since selftranslation is not an innocent practice, Whyte asserts (2002: 69) that it "occurs in situations of exile or of crude subjugation where one language is attempting to take the place of another". This is true of all those countries that have suffered from colonialism and/ or imperialism in any form. Therefore, self-translation in these contexts has political, cultural and social consequences. It should be regarded as a common practice among those committed writers that regard their own writings as an important part of the struggle against the imposed (neo)colonial power. These writers do not write only to entertain their audience but to mobilise it. They are aware of the political force of their writings, which in many cases have led them to be imprisoned or forced into exile.

The aim of the present work is to describe self-translation as a common phenomenon in postcolonial contexts, and in particular, in African countries. Ashcroft et al.(1989: 39) distinguish "three main types of linguistic groups within postcolonial discourse: monoglossic, diglossic and polyglossic". African countries are diglossic societies, in "which bilingualism has become an enduring societal arrangement"and in which english ${ }^{2}$ has generally been adopted as the language of government and commerce, and the use of english demonstrates some of the more pronounced forms of language variance"(A shcroft 1989: 39).

The European expansion in Africa took place at a great speed. The Berlin Conference in 1884 was the starting point of what we call "the scramble for Africa". At this conference different European nations (Great Britain, France, Portugal, Belgium, Germany, Italy and Spain) agreed to share the African continent among themselves. By this time A frica represented the last horizon for European imperialism. The people of Africa suffered from displacement and resettlement of their communities. The European colonisers despised and denigrated anything African, destroying whole cultures and civilizations. They also attacked traditional African religions, eliminated autochthonous forms of social organization and imposed new models of education and behaviour.

Less than a quarter of a century later, by the end of the 19th century, the process of decolonisation had already started, although it was only after the Second World War that most colonies achieved political independence. In most ca-

${ }^{2}$ English is the result of the abrogation and appropriation of the English language as a way of resistance. English vs. english (Cf. Ashcroft 1989). 
ses the decolonisation process entailed anti-colonial struggles, often armed struggles. In this process, language was also used as a way to resist colonial power, as colonised people appropriated and challenged the language of the colonisers to create new ways of representation. Translation also played a major role in the process of decolonisation. As Gentzler (2001: 176) points out, Rather that using translation as a tool to support and extend a conceptual system based upon Western philosophy and religion, postcolonial translators are seeking to reclaim translation and use it as a strategy of resistance, one that disturbs and displaces the construction of images of non-western cultures rather than reinterpret them using traditional, normalized concepts and language.

Thus, translation becomes a subversive activity. In Gentzler's work Contemporary Translation Theories (2001), he analyses Niranjana's theory of postcolonial translation that advocates the use of deconstruction as a powerful strategy when translating. Niranjana, deeply influenced by Benjamin, focuses on terms such as release, re-creation, liberate, and breaks. These terms are even more frequent when the translator is the writer himself. In postcolonial translation heterogeneity over homogeneity, and the contamination of translation over the purity of the original, are more valued (Gentzler 2001). The question of equivalence takes on a different perspective when one speaks of postcolonial (self)translation.

\section{The choice of language in African countries.}

Language has been one of the most effective and powerful weapons of coIonial discourse. In African countries, there was a great linguistic diversity (Swahili, Zulu, Yoruba, Luo, Luhya, Shona, Ibo, Hausa, Dhoulo, Luluhya, Kikamba, Kimasai, Kigiriama, Wol of, Lingala, Kiswahili, Kimbundu, Arabic, Amharic, Gikuyu, Afrikaans, etc.) until colonisers imposed their language. Thus, vernacular languages were thrown to the periphery, while the language of the colonisers occupied the centre. According to Ngugi wa Thiong'o (1986: 5), the Kenyan scholar and writer, African countries, as colonies and even today as neocolonies, came to be defined and define themselves in terms of the languages of Europe: English-speaking, French-speaking or Portuguese-speaking African countries.

The language of the Empire was imposed in every aspect of daily life. $\mathrm{Na}$ tive languages were also suppressed in the education system. They were associated with negative qualities, and they were denigrated, marginalized and banned. This resulted in the empowerment of the English (French or Portuguese) language, which became the language of prestige. Most African countries lost their languages, and since language is a carrier of culture they also lost part of their culture. Western culture, languages and values were imposed upon colonised people. European languages gave access to better jobs and better lives. Writers al so started to use them in their works because "during the imperial period writing in the language of the imperial centre is inevitably, of course, produced by a literate elite whose primary identification is with the colonizing power"(A shcroft et al. 1989: 5). 
The choice of language by African writers has been a controversial issue among postcolonial theorists and scholars (Williams 1991). The question has been thoroughly discussed in the field of the philosophy of language as well as in postcolonial theory. From a postcolonialist perspective, the election of Ianguage is determinant since it is related to questions of identity, nationalism and (anti)colonial discourse among others. In African countries language has been not only a weapon to impose Western culture but also a weapon to resist it. As self-translation implies a dual choice of language(s) it should be a relevant concern for postcolonial theory. The major point is whether or not Africans who write in European languages can be considered African writers. Since in A frican philosophy language is a tool of knowledge (Kunene 1992), the choice of language for writing is also a decisive subject. According to Kunene, African writers who write in European languages cannot really be considered African writers because, since language is a carrier of philosophical values, they cannot be representative of African values. On the contrary, writers who write in a foreign language are already part of the foreign institution; to one extent or another, they have adopted foreign values and philosophical attitudes, and they variously seek to be a member of that culture. (...) they speak from the perspective provided for them by the effective apparatus of mental control exercised by the former colonial power (Kunene 1992: 32).

Thus, we face one of the aporias in postcolonial theory: African writers who write in European languages but who are included as representatives neither of European Literature nor of A frican Literature but as A frican writers writing in European languages. How, then, should African Literature be defined? To some writers and scholars, the choice of writing in A frican languages is an assertion of African Literature and African values, although vernacular languages have been commonly used as a way to assert nationalism. What should we think of those writers who choose to write not only in the language of the oppressors, nor only in the language of the oppressed, but in both languages? This is the case of self-translators. They do not reject their roots or their past, nor they do reject History. They have been colonised and in many cases they have internalised that colonialisation. It can be said that they are being decolonised through the translation of their own writings. Then self-translation can be regarded as the way to live with the tensions produced by an internalised experience of colonialism.

A powerful strategy used in the decolonisation process is related to the use of the language of the colonisers. The english language has participated actively in the anti-colonial struggle. In The Empire Writes Back the two main textual strategies used to resist imperialism in postcolonial writing are described as follows: The first, the abrogation or denial of the privilege of English involves a rejection of the metropolitan power over the means of communication (...). The second, the appropriation and reconstitution of the language of the centre, the process of capturing and remoulding the language to new usages, marks a separation from the site of the colonial privilege (Ashcroft et al., 1989: 38). 
Self-translation can be regarded as yet another strategy to resist colonialism and imperialism. We might hypothesize that the author-translator translates his works himself in order to preserve the particular characteristics of his culture and his language. At the same time a dial ogue between the coloniser and the coIonised is created. Most of the self-translators in A frican countries translate from their native tongues into English or French. Since they have a hybrid identity, they are able to create a double work that fits each language and culture. Selftranslation is not governed by principles of equivalence or adequacy. Selftranslation is a recreation of the original and it can only be understood in that process of recreation. It is a hybrid work that functions as a complementary work of a previous text.

\section{Self-Translation in A frica.}

In an attempt to classify translations in African countries, Moradewun Adejunmobi (1998) distinguishes three major types: (1) compositional translations, those translations characterised by the "absence of original versions in indige nous texts"(A denjunmobi 1998: 165). A frican ideas, values, language and narrative are translated in a European language, which is modified, indigenised and foreignized in order to preserve the African languages; (2) authorized translations, the "European-language versions of A frican-language texts"(A denjunmobi 1998: 170). In this case, there exists an original text written in a native African language prior to the publication of the European-language text; and finally, (3) complex translations, characterised by the presence of both languages in the text by means of the code-switching technique. In his definition of authorized translations, Adenjunmobi (1998: 170) uses the term version to refer to the target text, a nuance that coincides with our notion of self-translation as a recreation of the original text, its complementary text. Authorized translations are exemplified in Adenjunmobi's article by the works of Kunene, Ngugi and p'Bitek who are mentioned in this paper as self-translators. Thus, authorized translations could be tantamount to self-translations? He also analyses the main strategies employed in the authorized translations, regardless of the fact that the translations have been done by the author themselves. If a descriptive-comparative study was carried at on self-translation, they could be validated as strategies used when selftranslating. Instead of speaking about equivalence, Adejunmobi mentions fluency as "the dominant strategy in translations of A frican language texts into European languages, even in instances where such translations have been undertaken by the author"(Adejunmobi 1998: 171). The result is a normalized translation that "seeks to convey the meaning but not the language of the original"(Adejunmobi 1998: 171). The translated text is not presented as an equivalent text of an original text, but as a text written in a European language. It is not a foreignized translation but a normalized one, a version of another text written in a native $A$ frican language. 
In the postcolonial situation of most African countries, self-translators usually share certain biographical features that have deeply influenced their writings. Most of them are scholars and professors in Western universities as well as revolutionaries in their native countries. All of them seem to share a bilingual identity due to the consequences of colonialism: they are competent in two or more languages, and they have also lived outside the colonial context. Despite being very cosmopolitan, they are deeply concerned with native African languages, since most of them have been involved with this issue as scholars. African writers in Africa want to promote A frican languages for writing and African literature in native languages, because the colonial power has destroyed their literary tradition. African writers have often been included in anthologies as "African writers in English", as a continuation of English literary tradition. There exists a close relationship between the writers and their work. Their writings are an important part of their lives, as they are part of their struggle against colonialism. Their writings usually have political connotations, and consequently their self-translations have them too. These writers are committed to a struggle and self-translation should be studied as a strategy in this struggle.

Of great relevance is the fact that seventeen out of twenty-one selftranslators depicted in the table presented in section 5, are from South A frica. It reveals that self-translation is a common practice in South A frica, where English is the mother tongue of three millions people, while Afrikaans is the mother tongue of six million people. In 1925 Afrikaans was recognised as a distinct language. Since the National Party won the elections and implemented A partheid politics, Afrikaans had a privileged and protected status. A frikaans was the language of the oppressors rather than English. In 1975 the A partheid government tried to impose Afrikaans as the only language for education in secondary schools resulting in the violent Soweto riots of 1976. As the use of Afrikaans for writing implied political connotations, it could be said that South A frican selftranslators translate themselves from Afrikaans into English as a way to reject A partheid. Fortunately, nowadays Afrikaans is only one of the eleven official languages of South Africa together with English, Ndebele, Pedi, Sotho, Swazi, Tsonga, Tswana, Venda, Xhosa and Zulu. An in-depth study of the particular historical and political circumstances of South A frica could demonstrate the significant role played by self-translation. Writers in South Africa are mostly antiapartheid, and in many cases, they were forced into exile and even sent to prison.

Among those South African writers who were forced into exile, we find Archivald Campbell Jordan. He was a freedom fighter and a revolutionary, who was involved in a number of organizations and movements, and healso supported the general strike that brought about the events in Sharpeville. As a consequence, by 1962, Jordan was forced into exile and he sought residence in Tanzania, the United Kingdom and the United States, where he taught African Languages and Literature at the University of Wisconsin until his death in 1968 . He 
received his MA in Bantu Languages. Thus, he did much of his creative writing in Xhosa, his mother tongue. His most famous work is Ingqumbo yeMinyanya, which helater translated into English as The Wrath of the Ancestors. Breyten Breytenbach was also an anti-apartheid writer from South Africa who was in exile in Paris. When he returned to South Africa on a clandestine trip in 1975, he was sentenced to nine years in jail for political reasons. These experiences are reflected in his poems and other writings, which have been translated from Afrikaans into English by the author himself.

Another anti-apartheid writer and scholar from South Africa is Mazini Kunene, who was in exile in Britain and the USA for 34 years. He was a founding member of the Anti-A partheid Movement in Britain, Professor of African Languages and Literatures and a prolific writer. Kunene has been committed to the literary tradition of Africa and particularly concerned with the oral Zulu tradition. He writes in Zulu and then he translates himself into English. Among his self-translations are: Zulu Poems (1970), Emperor Shaka the Great: A Zulu Epic (1979), Anthem of the Decades: A Zulu Epic Dedicated to the Women of Africa (1981), all of them translated from Zulu into English. Emperor Shaka was first published in English for political reasons. While Kunene is aware of the language choice issue, he translates his works because of a need to reach a far wider audience. As Kunene himself says, "I have, in translating my work from Zulu to English, cherished particularly the thought of sharing our history and literature with the many peoples of Africa and also of other parts of the world"3. There is a need to promote the native languages as well as a need to share this commitment to his culture with others. Kunene might be considered a free self-translator. Although words in Zulu and English may even cover similar concepts, they have different connotations. In the initial notes to Emperor Shaka the Great: A Zulu Epic, Kunene says: The translation of the epic does not claim to correspond word for word with the original Zulu epic. I have tried to give a faithful but free translation of the original. I have also cut out a great deal of material which would seem to be a digression from the story, a style unacceptable in English but characteristic of deep scholarship in Zulu. (...) Many concepts in Zulu are either untranslatable or they require reinterpretation. Many words in English do not mean exactly the same things in Zulu. (...) A word-for-word translation from Zulu to English was thus made impossible. ${ }^{4}$

The need to be read by a far wider public is one of the main reasons for a writer to translate himself. Uys Krige, playwright, writer and translator, translates his plays from Afrikaans to English although his Afrikaans is superior to his English. He is a bilingual writer who needs to find an audience that is both larger and perhaps more sympathetic than the relatively small A frikaans-speaking public. André Philippus Brink is another South African anti-apartheid writer and self-translator. His book Kennis van die Aand (1973) was the first book writ-

\footnotetext{
${ }^{3}$ Quoted in notes compiled by Prof. J.C. Santoyo.

${ }^{4}$ Quoted in notes compiled by Prof. J.C. Santoyo.
} 
ten in Afrikaans that was banned by the government of South Africa for being pornographic. As a consequence, Brink decided to translate it into English the following year as Looking on Darkness "pour trouver à l'étranger l'audience qu'on lui refuse dans son pays. C'est le début de la reconnaissance internationale". (www. Librairie) Since then, he has written all his works in both Afrikaans and English.

We can also find self-translators outside the South African context. The Ugandan writer Okot $\mathrm{p}$ 'Bitek is deeply concerned with Acoli traditional songs. He first wrote Wer pa Lawino(1969) in Acoli and then translated it into English as Song of Lawino. G.A. Heron, in the introduction to the edition of Song of Lawino and Song of Ocol, says, "the writer chose to make a very literal translation of Song of Lawino. The main differences between the two versions are the rearrangement of the order of certain sections within the chapters, the filling out of some descriptions of things unfamiliar to readers of the English version". Although certain aspects of meaning, rhythm and rhyme are lost in this kind of translation, "a less literal translation would have involved the intrusion of foreign elements into his poem." ${ }^{5} \mathrm{~A}$ further analysis proves that Heron is wrong. Taban lo Liyong, a scholar, the writer's friend and translator of an English version of Wer pa Lawino, noted, when translating the poem, that the last chapter had not been translated. In his view, "Okot did not translate Wer pa Lawino into Song of Lawino. He wrote two books: Wer pa Lawino (a very deep, philosophical book in Acholi; a book of morals, religion, anthropology, and wisdom) and a second light book, Song of Lawino"(Liyong 1993 :88). Healso published a bilingual edition of The Horn of my Love, A coli-English. To Kunene, the A frican thought system is different from the Western one and, every work acquires a different interpretation depending on the reader.

C. E. Moikangoa is another writer who advocates the promotion of literature in the African vernacular languages. His short story Sebolelo Comes Home is a literal English translation from Southern Soto.

\section{N gugi wa Thiong'o: conversion, self-translation and decolonisation.}

In the present paper Ngugi wa Thiong'o has been chosen as the most re presentative and committed writer in the anti-colonial struggle because of his rejection of the English language for his writings. Ngugi was born in Kenya, a colonised country under British rule until 1963. Ngugi's family belonged to Kenya's largest ethnic group, the Giyuku. Ngugi attended a missionary school at Kamaandura in Limuru, the Karinga School in Maanguu, and the Alliance High School in Kikiyu. During these years Ngugi became a devout Christian. Later, he rejected Christianity, and in 1976 he changed his name from James Ngugi, which he considered "colonial"to Ngugi wa Thiong'o. This is just another feature of the decolonisation process experienced by this author. In 1964 he

\footnotetext{
${ }^{5}$ Quoted in notes compiled by Prof. J.C. Santoyo.
} 
went to England to pursue graduate studies at Leeds University. The same year he wrote his first novel Weep Not, Child (1964), which was also the first novel published in English by an East African author. After its great success, he continued publishing in English: The River between (1965); A Grain Of Wheat (1967) and Petals of Blood (1977), his last novel written in English. The first work written in Gikuyu was the play Ngaahika Ndeenda (translated in 1982 as I will Marry when I Want) performed in 1977 in the Kammiriti Theatre to great acclaim. A week later, Ngugi was imprisoned. A mnesty International declared Ngugi a prisoner of conscience. Since then, he has lived in exile in England and in the United States and worked at New York University. Caitaani Mûtharabainî was written during his detention and translated into English in 1980 by the author himself as Devil on the Cross. N gugi is al so a prolific scholar who has fought for A frican Literature to occupy a central position in the curriculum. To N gugi, an African Literature and Languages Department should be created at African universities. In Decolonising the Mind: The Politics of Language in African Literature (1986), he says goodbye to the English language in his initial statement: In 1977 I published Pe tals of Blood and said farewell to the English language as a vehicle of my writing of plays, novels and short stories. All my subsequent creative writing has been written directly in Gikuyu language (...) However, I continued writing explanatory prose in English (...). This book, Decolonising the Mind, is my farewell to English as a vehicle for any of my writings. From now on it is Gikuyu and Kiswahili all the way. - However, I hope that through the age old medium of translation I shall able to continue dialogue with all (N gugi 1986: xiv).

This linguistic conversion has been deeply analysed by postcolonial theorists, critics and scholars. As we have mentioned before, the issue of language choice is central to African writers. On the one hand, Ngugi's position can be examined in relation to his concern with the philosophy of language, as Simon Gikandi (1992: 133) points out: " $\mathrm{H}$ is evolution as a novel ist and literary critic has been motivated by his obsession with language as a structuring category of culture, thought and experience". When Ngugi started to write, a universal, ahistorical and liberal notion of language prevailed in his works. Ngugi viewed language as a way to gain access to the human essence, a way to individual freedom (Gikandi 1992). Despite this idealistic notion of language, Ngugi cannot run away from the historicity that surrounds him. He realized that literature is a reflection of history and culture. In order to achieve cultural liberation, political liberation is first needed. Therefore, he came back to his roots and "his primary goal was to articulate a more coherent materialist theory of linguistic practice and to A fricanize the colonial language so that it could help liberate A frican culture from the surviving institutions of imperialism"(Gikandi 1992: 136). At this stage he was not yet deeply concerned with the choice of language; his focus was on with the detrimental influence of the institutions that preserved the coIonial rule. From this point, he moves from the ideology of language to a more functionalist view of language. He assumes the function of language as a wea- 
pon in its complex dimension of colonial struggle. By using his native language, he is contributing to the creation of a national literature and culture (Gikandi 1992).

On the other hand, the contradictions found in Ngugi can also be analysed in relation to the theories proposed by the political theorist Frantz Fanon. In the first half of the $20^{\text {th }}$ century, two main ideological movements emerged to resist imperialism. The first was a cultural and political movement called "PanAfricanism", which tried to establish political and cultural links between black populations in Africa, the Caribbean and the U.S.A. The second one, Négritude, was the creation of Leopold Sedar Senghor and Aine Césaire. It was a cultural rather than a political movement and it was centered on the vindication of an African identity based on the celebration of blackness. Although both movements contributed to the decolonisation process, Fanon criticised these cultural movements because they were based on the achievement of an African Culture re gardless of the specifics that characterise each nation. They were not based on political, historical, social or economic factors but on a shared African past. Despite their common African roots, each A frican nation should focus on to its particular political, historical and economic circumstances in order to reach a national consciousness. In Fanon's view these sorts of cultural movements “lead to the exaltation of cultural manifestations which are not simply national but continental, and extremely racial"(Fanon 1965: 175).

Since the publication of The Wretch of the Earth (1965) Fanon is considered the father of "anti-colonialism" and of the movement called "National Culture". According to Fanon the nation is the battlefield for anticolonial resistance because "it is the fight for national existence which sets culture moving and opens to it the doors of creation"(Fanon 1990: 197). National liberation is the condition for the existence of culture. In his article "On National Culture", Fanon urges artists and intellectuals "to build up their nations" to achieve a national consciousness (Fanon 1965). Thus, the native African intellectual should be also a politically committed writer, not merely a mouthpiece for the rich African culture. This is the only effective way to resist colonialism. According to Fanon, who was also influenced by Marxism, national consciousness and national culture cannot be separated from each other. In order to achieve national consciousness the native intellectual needs "to turn backwards towards his unknown roots and to lose himself at whatever cost in his own barbarous people"(Fanon 1965: 175). To Fanon, being liberated from the colonial power implies a painful evolution composed of three major phases:

1. The native intellectual attempts to become part of the European tradition. The native intellectual assimilates the Western culture and his work is a clear proof of this assimilation.

2. The native intellectual rejects Western models by asserting the cultural history of his own people. He turns back to his past and his people, feeling that he should escape from the Western power. It is a nostalgic going back to the 
past. In this cult of the past the native intellectual ignores the day-to-day struggles.

3. The fighting phase: the native intellectual becomes directly involved in the people's struggles against colonialism. His main concern is not to celebrate his roots and his people but to mobilise his people. This results in a "fighting literature, a revolutionary literature, and a national literature"(Fanon 1965: 179). The writer/ artist becomes an awakener of the people. This national consciousness is the greatest manifestation of culture (Fanon 1965).

A parallelism can be established between these stages described by Fanon and the decolonisation process experienced by $\mathrm{N}$ gugi who has been deeply influenced by Fanon and felt this sense of social commitment as a writer. He has contributed to create a Kenyan national culture as proposed by Fanon. The first phase would correspond to his first three English novels. A foreign language and the European literary canon were imposed on him at school. As a result, he was influenced by the literary trends of the Western culture. He started writing in English, as it was the language of his education. English writers such as D.H. Lawrence or Joseph Conrad inspired his earliest works (Gikandi 1992). Then, N gugi grew dissatisfied with the Western models because they could not reflect the rich oral tradition of African literature and the particularities of his culture. Ngugi began to write in Gikuyu and then he translated his own works. The second phase would correspond to the immersion of the writer in his own culture and roots. N gugi began to write in his mother tongue in 1977 (after seventeen years of writing in English). His first work written in Gikuyu was the result of close contact with his people. He had to write a play for a small village, where Gikuyu was the only language of communication. N gugi became aware not only of the struggles of the people but also of his own native oral tradition. Once the play was performed, the Kenyan government banned it and Ngugi was sent to prison. This detention led to N gugi 's assertion of his politics of language and he entered the third phase. His works in English did not present any threat to the neo-colonial power because they only reached a bourgeois minority and an alienated elite. However, his Gikuyu play addressed the working-class of Kenya that represents ninety per cent of the total population in Kenya. When the target audience is the peasantry, the work is seen as a call for the revolution. After being in prison in 1978, Ngugi abandoned the English language in favour of his native tongue: Gikuyu. In this third phase Ngugi writes only in Gikuyu and the aim of his works is to "shake his people". The function of the Gikuyu texts differs from that of the English ones. In Matigari Ma Njirûûngi he explicitly wanted to mobilise his people. The Kenyan government confiscated the play, although its message had al ready spread throughout the country. It was considered a subversive play and its public readings a subversive activity of the Kenyan people. The author had suffered a process of decolonisation, which was reflected in the language he used to write. Once he was decolonised, he wanted his people to be decolonised too. He became an active agent by mobilising his people in his nati- 
ve language. He rejected English as the language for his creative writing as a way to reject neo-colonialism. Rejection and subversion are different responses to the dominance of the English language, and both take place in the process of decolonisation: The process of radical decolonisation proposed by Ngugi wa Thiong'o is a good demonstration of the first alternative. Ngugi's programme for restoring an ethic or national identity embedded in the mother tongue involves a rejection of English, a refusal to use it for his writing (...) This stance of rejection rests upon the assumption that an essential Gikuyu identity may be regained, an identity which the language of the coloniser seems to have displaced or dispersed (A shcroft et al.1989: 283).

Ngugi proposed a return to native African languages for writing because "the choice of language and the use to which language is put is central to a people's definition of themselves in relation to their natural and social environment, indeed in relation to the entire universe". (N gugi 1986: 4). Healso stopped translating his own work because he had "lost interest in the use of the English language"(Jussawala 1992: 34). Self-translation by Ngugi can be regarded as a necessary step to being decolonised. He has since become involved in the people's struggle against colonialism because the intellectual and bourgeois elite of Kenya whom English works address does not represent these people. In an interview with by Feroza Jussawala and Reed Way Dasenbrock in 1992, N gugi points out that an African writer who writes in European languages is not addressing the African people, because ninety per cent of the people in Africa speak only African languages, not European languages (Jussawala 1992). N gugi urges African writers to write in African languages as the means to mobilise the African people because, The real language that one is looking for is the language of struggle, the language of transformation of our various societies. Eventually this language can only be found in the actions and feelings and thoughts and experiences of the working people. Therefore to discover that real language of struggle is to find an identity, to identify oneself with the struggles of the working people (Jussawalla 1992: 28).

This can be identified as the awakening of the native intellectual from his alienation in the culture of the oppressor. It is the manifestation of his national consciousness, since he has changed his target audience from the audience defined by the oppressor to his own people (Mazrui and M phande 2000).

\section{A descriptive approach to self-translation.}

In the following section, we will describe some features of the most representative self-translators in Africa. The table ${ }^{6}$ presented below provides an overview of the rich material available for further studies on the subject. It constitutes the first attempt to describe the phenomenon of self-translation in Africa and the first systematic and descriptive approach to self-translation within a postcoIonial context. If translations are "cultural facts existing in a given culture"(Toury 1995), we should study self-translations as a particular case of transla-

\footnotetext{
${ }^{6}$ This table relies on notes compiled by Prof. J.C. Santoyo.
} 
tion that should be described and studied. Since this study is framed within a descriptive approach, we are mainly concerned with answering the following questions in relation to self-translation: who, why, to whom, how, in what context. It appears relevant that we know beforehand the answers to some of the questions: the translator is the author him/ herself who translates for a different target audience in a postcolonial context. The reason why these authors translate themselves can be found in Fanon's philosophical view of writing: they contribute to the creation of a national consciousness and a national literature. Our ignorance of the A frican languages does not allow us to answer the question as to how they translate. But, we encourage other researchers to pursue this issue.

The following table is divided into five columns: (1) author;(2) languages; (3) self-translations; (4) jobs and (5) comments. It includes some biographical data on the author-translator presented as well as some comments on his/ her reasons for self-translating and the political consequences which (s)he had to face due to publication of his/ her writings. 


\begin{tabular}{|c|c|c|c|c|}
\hline Authors & Languages & Self-translations & Jobs & Comments \\
\hline $\begin{array}{l}\text { Bakkes, } \\
\text { Margaret. } \\
\text { South Africa }\end{array}$ & $\begin{array}{l}\text { Afrikaans- } \\
\text { English }\end{array}$ & $\begin{array}{l}\text { Short stories: Sing vir } \\
\text { ons, Matilda; Oon } \\
\text { Douwtjie se fees; Tuis- } \\
\text { koms. (Afrikaans- } \\
\text { English) }\end{array}$ & Writer & $\begin{array}{l}\text { Her works are now } \\
\text { available to a far } \\
\text { wider reading } \\
\text { public. }\end{array}$ \\
\hline $\begin{array}{l}\text { Breytenbach, } \\
\text { Breyten } \\
(1939-) \\
\text { South Africa }\end{array}$ & $\begin{array}{l}\text { Afrikaans- } \\
\text { English }\end{array}$ & $\begin{array}{l}\text { Poems: “My heritage”, } \\
\text { "The Truth", “The Let- } \\
\text { ter"(A frikaans- } \\
\text { English) }\end{array}$ & $\begin{array}{l}\text { Writer Pain- } \\
\text { ter }\end{array}$ & $\begin{array}{l}9 \text { years in prison in } \\
\text { South A frica. Exile } \\
\text { in Paris. }\end{array}$ \\
\hline $\begin{array}{l}\text { Brink, André } \\
\text { (1935-) } \\
\text { South Africa }\end{array}$ & $\begin{array}{l}\text { Afrikaans- } \\
\text { English }\end{array}$ & $\begin{array}{l}\text { Kennis van DieAand- } \\
\text { Looking on Darkness } \\
\text { (Afrikaans-English). 1st } \\
\text { book banned in South } \\
\text { A frica. Since then, he } \\
\text { has translated all his } \\
\text { works into English. }\end{array}$ & $\begin{array}{l}\text { Writer } \\
\text { Professor }\end{array}$ & $\begin{array}{l}\text { Anti-apartheid. He } \\
\text { lived in Paris. In- } \\
\text { ternational recog- } \\
\text { nition. }\end{array}$ \\
\hline $\begin{array}{l}\text { Campbell } \\
\text { Jordan, } \\
\text { Archivald } \\
\text { (1906-1969) } \\
\text { South Africa }\end{array}$ & $\begin{array}{l}\text { Xhosa } \& \text { ot- } \\
\text { her natives } \\
\text { tongues- } \\
\text { English }\end{array}$ & $\begin{array}{l}\text { Ingqumbo yeMinyanya- } \\
\text { The Wrath of the Ances- } \\
\text { tors (Xhosa- English). } \\
\text { Poem: "You Tell me to } \\
\text { Sit Quiet" }\end{array}$ & $\begin{array}{l}\text { MA in Bantu } \\
\text { languages. } \\
\text { Lecturer, } \\
\text { scholar, wri- } \\
\text { ter, linguist, } \\
\text { literary critic, } \\
\text { poet, musi- } \\
\text { cian. }\end{array}$ & $\begin{array}{l}\text { Humanist, nation- } \\
\text { alist, freedom } \\
\text { fighter, revolution- } \\
\text { ary. He became } \\
\text { involved in a no of } \\
\text { organizations \& } \\
\text { movements. He } \\
\text { was forced into } \\
\text { exile in } 1962 \text {. }\end{array}$ \\
\hline $\begin{array}{l}\text { Cussons, } \\
\text { Sheila } \\
(1922-) \\
\text { South Africa }\end{array}$ & $\begin{array}{l}\text { Afrikaans- } \\
\text { English; } \\
\text { Spanish }\end{array}$ & $\begin{array}{l}\text { Poems (A frikaans- } \\
\text { English) }\end{array}$ & $\begin{array}{l}\text { Writer, poet, } \\
\text { translator. }\end{array}$ & $\begin{array}{l}25 \text { years in Spain } \\
\text { before returning to } \\
\text { South Africa in } \\
1982 .\end{array}$ \\
\hline $\begin{array}{l}\text { De Lange, } \\
\text { Johann } \\
(1959-) \\
\text { South Africa }\end{array}$ & $\begin{array}{l}\text { Afrikaans- } \\
\text { English }\end{array}$ & $\begin{array}{l}\text { Poems: “Koos Prins- } \\
\text { loo", "Soldier", "Ima- } \\
\text { go", "Two Sailors Piss- } \\
\text { ing"(Afrikaans- } \\
\text { English) }\end{array}$ & $\begin{array}{l}\text { Translator, } \\
\text { teacher, poet. }\end{array}$ & \\
\hline
\end{tabular}




\begin{tabular}{|c|c|c|c|c|}
\hline $\begin{array}{l}\text { Eybers, } \\
\text { Elizabeth } \\
\text { Françoise } \\
\text { (1915- ) } \\
\text { South Africa }\end{array}$ & $\begin{array}{l}\text { Afrikaans- } \\
\text { English }\end{array}$ & $\begin{array}{l}\text { Poem: “Narra- } \\
\text { tive”(A frikaans- } \\
\text { English) }\end{array}$ & $\begin{array}{l}\text { Poet, writer, } \\
\text { translator. }\end{array}$ & $\begin{array}{l}\text { She has lived in } \\
\text { The N etherlands } \\
\text { since } 1961 .\end{array}$ \\
\hline $\begin{array}{l}\text { Hambindge, } \\
\text { Joan } \\
\text { (fl. 1995) } \\
\text { South Africa }\end{array}$ & $\begin{array}{l}\text { Afrikaans- } \\
\text { English }\end{array}$ & $\begin{array}{l}\text { Poem: “Departu- } \\
\text { re”(Afrikaans-English) }\end{array}$ & $\begin{array}{l}\text { Lecturer in } \\
\text { Afrikaans. } \\
\text { Poet }\end{array}$ & \\
\hline $\begin{array}{l}\text { Jonker, Ingrid } \\
(1933-1965) \\
\text { South Africa }\end{array}$ & $\begin{array}{l}\text { Afrikaans- } \\
\text { English }\end{array}$ & $\begin{array}{l}\text { Selected Poems (Afri- } \\
\text { kaans-English) }\end{array}$ & Poet. & $\begin{array}{l}\text { She committed } \\
\text { suicide. Daughter } \\
\text { of a nationalist Af- } \\
\text { rikaner. }\end{array}$ \\
\hline $\begin{array}{l}\text { Joubert, Elsa } \\
\text { (1922-) } \\
\text { South Africa }\end{array}$ & $\begin{array}{l}\text { Afrikaans- } \\
\text { English }\end{array}$ & $\begin{array}{l}\text { Die Swerfjare van poppie } \\
\text { Nongena- Poppie (A fri- } \\
\text { kaans- English) }\end{array}$ & $\begin{array}{l}\text { Writer, jour- } \\
\text { nalist. }\end{array}$ & $\begin{array}{l}\text { She writes travel } \\
\text { books. Poppie was } \\
\text { a best seller in Af- } \\
\text { rikaans, won an } \\
\text { award from the } \\
\text { Royal Society of } \\
\text { Lit. in London. }\end{array}$ \\
\hline $\begin{array}{l}\text { Kotze. E. } \\
\text { South africa }\end{array}$ & $\begin{array}{l}\text { Afrikaans- } \\
\text { English }\end{array}$ & $\begin{array}{l}\text { Short stories: Feeste } \\
\text { (Afrikaans-English) }\end{array}$ & Writer & $\begin{array}{l}\text { Her works are now } \\
\text { available to a far } \\
\text { wider reading } \\
\text { public. }\end{array}$ \\
\hline $\begin{array}{l}\text { Krige, Uys } \\
(1910-1987) \\
\text { South Africa }\end{array}$ & $\begin{array}{l}\text { Afrikaans- } \\
\text { English }\end{array}$ & $\begin{array}{l}\text { The Sniper; The two } \\
\text { lamps; (A frikaans- } \\
\text { English); The way out } \\
\text { (English- A frikaans) }\end{array}$ & $\begin{array}{l}\text { War journal- } \\
\text { ist, play- } \\
\text { wright, bilin- } \\
\text { gual writer, } \\
\text { translator. }\end{array}$ & $\begin{array}{l}\text { South A frican ar- } \\
\text { my. Prison. He } \\
\text { transl ates himself } \\
\text { due to a need to } \\
\text { find an audience } \\
\text { both larger, \& per- } \\
\text { haps more sympa- } \\
\text { thetic than the rela- } \\
\text { tively small local } \\
\text { public. }\end{array}$ \\
\hline
\end{tabular}




\begin{tabular}{|c|c|c|c|c|}
\hline $\begin{array}{l}\text { Kunene, } \\
\text { Mazisi } \\
(1930-) \\
\text { South Africa }\end{array}$ & $\begin{array}{l}\text { Zulu- } \\
\text { English }\end{array}$ & $\begin{array}{l}\text { Zulu Poems (Zulu- En- } \\
\text { glish); Anthem of the } \\
\text { Decades: A Zulu epic } \\
\text { dedicated to the Women } \\
\text { of Africa; Emperor Shaka } \\
\text { (1st published the } \\
\text { translation, free trans- } \\
\text { lation) }\end{array}$ & $\begin{array}{l}\text { Professor } \\
\text { (A frican lan- } \\
\text { guages and } \\
\text { Lit), Scholar. } \\
\text { PhD: oral Zu- } \\
\text { lu tradition. } \\
\text { Poet. }\end{array}$ & $\begin{array}{l}34 \text { years of exile in } \\
\text { Britain \& the USA } \\
\text { Founding member } \\
\text { of the A nti A part- } \\
\text { heid M ovement in } \\
\text { Britain. 1st A frican } \\
\text { Poet Laureate. }\end{array}$ \\
\hline $\begin{array}{l}\text { Moikangoa. } \\
\text { C.E. } \\
(1879-) \\
\text { Lesotho }\end{array}$ & $\begin{array}{l}\text { Southern } \\
\text { Soto- Eng- } \\
\text { lish }\end{array}$ & $\begin{array}{l}\text { Short story: Sebolelo } \\
\text { Comes Home (Southern } \\
\text { Soto-English). }\end{array}$ & $\begin{array}{l}\text { Inspector of } \\
\text { education, } \\
\text { writer }\end{array}$ & $\begin{array}{l}\text { Literal translation. } \\
\text { He wants to pro- } \\
\text { mote literature in } \\
\text { the African in- } \\
\text { digenous lan- } \\
\text { guages with a } \\
\text { Christian theme. }\end{array}$ \\
\hline $\begin{array}{l}\text { Moumé Etia, } \\
\text { Isaac } \\
(1889-1939) \\
\text { Cameroon }\end{array}$ & $\begin{array}{ll}\text { Douala- } & \\
\text { German, } & \\
\text { French, } & \\
\text { English \& } \\
\text { Spanish }\end{array}$ & $\begin{array}{l}\text { Fables de Douala (bilin- } \\
\text { gual edition: } \\
\text { French/ Douala) Col- } \\
\text { lection of oral litera- } \\
\text { ture. Self-translation? }\end{array}$ & $\begin{array}{l}\text { Translator, } \\
\text { writer. }\end{array}$ & $\begin{array}{l}\text { Interpreter in the } \\
\text { German \& French } \\
\text { colonial admini- } \\
\text { strations. }\end{array}$ \\
\hline $\begin{array}{l}\text { p'Bitek, Okot } \\
(1931-1982) \\
\text { Uganda }\end{array}$ & $\begin{array}{l}\text { Acoli- } \\
\text { English }\end{array}$ & $\begin{array}{l}\text { Wer pa Lawino- Song of } \\
\text { Lawino (A coli-English), } \\
\text { The Horn of my Love } \\
\text { (bilingual edition: } \\
\text { English-A coli) }\end{array}$ & $\begin{array}{l}\text { Scholar, wri- } \\
\text { ter, professor. } \\
\text { Director of } \\
\text { Uganda's Na- } \\
\text { tional Thea- } \\
\text { tre. }\end{array}$ & $\begin{array}{l}\text { Concerned with } \\
\text { African oral tradi- } \\
\text { tion. }\end{array}$ \\
\hline $\begin{array}{l}\text { Rabie, Jan } \\
(1920-2001) \\
\text { South Africa }\end{array}$ & $\begin{array}{l}\text { Afrikaans, } \\
\text { English, } \\
\text { Dutch, } \\
\text { French. }\end{array}$ & $\begin{array}{l}\text { Waar Jy Sterwe-A man } \\
\text { apart (Afrikaans- } \\
\text { English) } \\
\text { Short story: Drought }\end{array}$ & $\begin{array}{l}\text { Writer, critic, } \\
\text { teacher, } \\
\text { translator. }\end{array}$ & $\begin{array}{l}\text { The injustice of } \\
\text { apartheid \& the } \\
\text { role of censorship } \\
\text { are the main topics } \\
\text { of his writings. }\end{array}$ \\
\hline Rosseau, Ina & $\begin{array}{l}\text { Afrikaans- } \\
\text { English }\end{array}$ & $\begin{array}{l}\text { Short stories: Onthou jy } \\
\text { vir Helena Lem?, Die bas } \\
\text { van die geelhoutboom } \\
\text { (Afrikaans-English) }\end{array}$ & Writer & $\begin{array}{l}\text { Her works are now } \\
\text { available to a far } \\
\text { wider reading } \\
\text { public. }\end{array}$ \\
\hline $\begin{array}{l}\text { Uus, } \\
\text { Pieter-dirk } \\
\text { (1945-) } \\
\text { South Africa }\end{array}$ & $\begin{array}{l}\text { Afrikaans- } \\
\text { English }\end{array}$ & $\begin{array}{l}\text { Plays: Selle ou Storie, } \\
\text { God's forgotten, Para- } \\
\text { dise is closing down (Af- } \\
\text { rikaans-English) }\end{array}$ & $\begin{array}{l}\text { Playwright, } \\
\text { director and } \\
\text { performer. }\end{array}$ & $\begin{array}{l}\text { Government ban- } \\
\text { ned and censored } \\
\text { most of his plays } \\
\text { during apartheid. }\end{array}$ \\
\hline
\end{tabular}




\begin{tabular}{|l|l|l|l|l|}
\hline \hline $\begin{array}{l}\text { van Hereden, } \\
\text { Ernst } \\
\text { South Africa }\end{array}$ & $\begin{array}{l}\text { Afrikaans- } \\
\text { English } \\
\text { of Death”(Afrikaans- } \\
\text { English) }\end{array}$ & $\begin{array}{l}\text { Afrikaans cri- } \\
\text { tic, travel wri- } \\
\text { ter, autobio- } \\
\text { grapher, poet. }\end{array}$ & \\
\hline \hline $\begin{array}{l}\text { Ngugi Thiongó, } \\
(\mathbf{1 9 3 8 - )} \\
\text { Kenya }\end{array}$ & $\begin{array}{l}\text { English, Gi- } \\
\text { kuyu }\end{array}$ & $\begin{array}{l}\text { Caitaani Mûtharabaint- } \\
\text { Devil on the Cross (Gi- } \\
\text { kuyu-English) }\end{array}$ & $\begin{array}{l}\text { Writer. Scho- } \\
\text { lar. Professor. } \\
\text { Playwright }\end{array}$ & $\begin{array}{l}\text { Prison. Exile. He } \\
\text { abandoned English } \\
\text { as a vehicle for } \\
\text { writing. He pro- } \\
\text { motes African lan- } \\
\text { guages \& A frican } \\
\text { Lit. }\end{array}$ \\
\hline
\end{tabular}

\section{Bibliography}

Adejunmobi, M. 1998. "Translation and Postcolonial Identity. African Writing and European Languages." The Translator, 4, (2), pp.163-181.

Ashcroft, B., Gareth Griffiths \& Helen Tiffin. 1989. The Empire Writes Back: Theory and Practice in Post-Colonial Literatures. London (Routledge).

A shcroft, B., G areth G riffiths \& H elen Tiffin (eds.). 1995. The Post-colonial Studies Reader. London (Routledge).

Fanon, F. 1965. The Wretched of the Earth. London (Macgibbon and Kee).

Fanon, F. 1990. The Wretched of the Earth. London (Penguin Books).

G entzler, E. 1993. Contemporary Translation Theories. London (Routledge). $2^{\text {nd }}$ ed.

Gikandi, S. 1991. "The Epistemology of Translation: Ngugi, Matigari, and the Politics of Language". Research in African Literatures, 22 (4), pp.161-167.

Gikandi, S. 1992. "Ngugi's Conversion: Writing and the Politics of Language". Research in African Literatures, 23 (1), pp.131-144.

Gurnah, A. 1991. "Matigari: A Tract of Resistance". Research in African Literatures, 22 (4), pp.169-172.

Holmes, J.S. 1988. "The Name and Nature of Translation Studies". In J.S. Holmes Translated!. Essays and Papers on Translation Studies. A msterdam (Rodopi), pp.67-80.

Jussawalla, F. \& Way Dasenbrock, R. 1992. "N gugi wa Thiong'o". In: Interviews with writers of the Post-Colonial world. Jackson (University Press of Mississippi), pp.24-41.

Kunene, M. 1992. "Problems in African Literature". Research in African Literatures, 23 (1), pp.27-44.

Liyong, T.L. 1993. “On Translating the Unstraslated: Chapter 14 of Wer pa Lawino by Okot p'Bitek". Research in African Literatures, 24 (3), pp.87-92.

López G aseni, J.M . 2001. "Un caso de autotraducción: la(s) obra(s) de Bernardo Atxaga. Sara izeneko gizona/Un espía llamado Sara". En: E. Pajares, R. Merino y J.M. Santamaría (eds.) Trasvases culturales: literatura, cine, traducción.3. Bilbao (Universidad del País Vasco UPV / EUH), pp.261-268. 
M azrui, A . \& M phande, L. 2000. “Orality and the Literature of Combat: The Legacy of Fanon". In: Peter Nazareth (ed.) Critical Essays on Ngugi wa Thiong'o. N ew York (Twayne Publishers), pp.228-248.

M bele, J. 1992. "Language in African Literature: An A side to N gugi". Research in African Literatures, 23 (1), pp.145-151.

N gugi wa Thiong'o. 1986. Decolonising the Mind: The Politics of Language in African Literature. London (Routledge).

O ustinoff, M. 2001. Bilinguisme d'écriture et auto-traduction. Julien Green, Samuel Beckett, Vladimir Nabokov. París (L'Harmattan).

Santoyo, J.C. 2002. "Traducciones de autor: una mirada retrospectiva". Quimera no 210, Enero 2002, pp.27-32.

Toury, G. 1995.Descriptive Translation Studies and Beyond. Amsterdam / Philadelphia (John Benjamins).

Whyte, C. 2002. "Against Self-Translation". Translation and Literature, 11 (1), pp.64-71.

Williams, K. 1991. "Decolonizing the Word: Language, Culture, and the Self in the Works of N gugi wa Thiong'o and Gabriel Okara". Research in African Literatures, 22 (4), pp.53-61.

\section{WEB pages:}

http://www.librairie-compagnie.fr/afrique-sud/auteurs (08-05-03)

http://www.digital.library.upenn.edu/women/_generate/SOUTH\%20AFRICA.html (12-03-03)

http://www.africanwriters.com/Writers/Default.asp (17-10-03)

http://www.emory.edu/ENGLISH/Bahri/Ngugi.html (27-05-03)

http://www.geocities.com/africanwrites/Boerpoets.html (08-05-03)

http://www.ufh.ac.za/collectioons/NAHECS/Cultural\%20Heritage/acjordan1.htm (08-05-03)

http://www.stellenboschwriters.com/rabijan.html (12-03-03)

http://www.kirjasto.sci.fi/ngugiw.htm (24-05-03)

http://cosmos.oninetspeed.pt/luis.mail/SAfrican/seuffefrika.html (20-10-03)

http://www.evita.co.za. (3-11-03) 